\title{
Distribution and dispersal ecology of Lobaria pulmonaria in the largest primeval beech forest of Europe
}

\author{
Olga Nadyeina $\cdot$ Lyudmyla Dymytrova $\cdot$ Anna Naumovych $•$ \\ Sergyi Postoyalkin - Christoph Scheidegger
}

Received: 25 September 2013/Revised: 5 August 2014/ Accepted: 16 August 2014/

Published online: 2 September 2014

(C) Springer Science+Business Media Dordrecht 2014

\begin{abstract}
Occupancy and density of the epiphytic lichen L. pulmonaria were studied in the mountains of Uholka-Shyrokyi Luh (Ukraine), which include the largest primeval beech forest in Europe. The lichen occupancy was assessed on 314 plots laid out on a systematic grid. Additional data on population density were collected from 483 trees growing both, on and between these plots. The trees harbouring L. pulmonaria were distributed very sparsely within Uholka-Shyrokyi Luh, and occupy nearly $10 \%$ of the studied perimeter. The generalized linear models showed that area of occupancy of L. pulmonaria was significantly influenced by altitude and canopy cover, whereas the species' density was explained by habitat types and slope exposition. Population density is higher at the timberline than in the interior forest or on lowland meadows. We found a bimodal altitudinal distribution of $L$. pulmonaria, with maxima below and above $900 \mathrm{~m}$ a.s.l., where it prefers forest stands with loose or scattered canopy. The preferred position of L. pulmonaria on host tree trunks depends on stand density and allows the species to get the necessary level of insolation also in shaded sites where it grows higher up on the trunk than in open stands. While L. pulmonaria occupied trees with various diameters, juvenile individuals are more frequent on small trees, but mature lichen individuals are predominantly found on trees of average or large sizes. Fertile individuals require specific environmental conditions, which are available at intermediate altitudes, related with sheltered light, and horizontal terraces on slopes with eastern exposition. In general, the primeval beech forest of Uholka-Shyrokyi Luh harbours a high percentage of juvenile thalli of L. pulmonaria, which lack vegetative propagules. Mature individuals have a
\end{abstract}

Communicated by Pradeep Kumar Divakar.

O. Nadyeina $(\bowtie) \cdot$ L. Dymytrova

M.G. Kholodny Institute of Botany, Tereschenkivska str. 2, Kiev 01601, Ukraine e-mail: nadyeina@gmail.com

O. Nadyeina $\cdot$ L. Dymytrova $\cdot$ C. Scheidegger

Swiss Federal Institute for Forest, Snow and Landscape Research WSL, Zürcherstrasse 111, 8903 Birmensdorf, Switzerland

A. Naumovych · S. Postoyalkin

Kherson State University, 40 Rokiv Zhovtnya str. 27, Kherson 73000, Ukraine 
low frequency of fruit bodies and reproduce mainly with vegetative diaspores. We interpret this as an indication of a currently growing population of $L$. pulmonaria within the area. We hypothesize that transboundary air pollution has decreased the lichens' population frequency and density and has altered the ratio of developmental stages in L. pulmonaria during earlier decades.

Keywords Carpathians - Epiphytic lichen - Topographic and forest-stand variables . Juvenile $\cdot$ Mature $\cdot$ Fertile

\section{Introduction}

Habitat degradation and loss, fragmentation and environmental pollution are amongst the most important causes of a dramatic decline of biodiversity worldwide (Groom et al. 2006). Nature reserves and integrative conservation instruments (Bollmann and Braunisch 2013) provide a comprehensive framework for biodiversity conservation in forest ecosystems, where spatio-temporal habitat dynamics and species characteristics interact with and relate to species persistence (Van Teeffelen et al. 2012). Integrative conservation instruments such as structural retention, old-growth stand protection or ecological process areas provide a minimum habitat quality for the majority of generalist species, do however not provide long-term existing niches for many habitat specialist, particularly species that depend on extended habitat tradition, e.g., lichens, fungi, insects (Bollmann and Braunisch 2013; Scheidegger et al.2010). Nature reserves provide habitat to specialist species but natural dynamics is likely to change special habitats such as old-growth structures over time (Bruun et al. 2006). This may lead to the disappearance of recolonization sources of old-growth dependent species in relatively small protected areas and consequently extinction becomes the dominant population process unless nature reserves are considerably larger than the largest disturbance patch size, including rare patches (Pickett and Thompson 1978). As more and more of the earth is modified by humans, the mismatches in scale between present nature reserves and the natural dynamics of ecosystems become more pronounced (Bengtsson et al. 2003).

Epiphytic lichens are among the most suitable indicator taxa of forest biodiversity (Hansson 1997) and under certain climatic conditions many species appear to require continuity of old trees (Kuusinen 1994, 1996; Nilsson et al. 1995; Rose 1976; Tibell 1992). However, species that depend on old-growth forests in one region may be less specific under more favourable climatic conditions. Therefore the general utility of lichens as indicators of woodland ecological continuity has recently been questioned (Whittet and Ellis 2013). Although these species often require minimal habitat size, e.g., a single tree, to grow and survive for many decades but for the maintenance of viable populations, most of these species depend on extended old-growth structures such as veteran trees, and extended habitat tradition that includes a spatio-temporal continuum of old-growth forest structures at a small spatial scale. However, in small protected areas old-growth forest dependent lichen populations may be extremely small and thus face an increased risk of local extinction if the reserve is small compared to the minimum dynamic area (Pickett and Thompson 1978). Increased extinction frequency in small habitat patches could thus decrease the indicator value of species because of false negatives in small reserves. In forest key habitats in southern Finland $20 \%$ of the populations tree colonizing lichen species disappeared within $<10$ years because their only host tree had fallen, a snag had 
further decomposed, or for an unknown reason (Pykälä 2004). Habitat requirements, abundance and density of possible indicators of forest ecological continuity have therefore to be studied in large protected areas where the requirements for a colonisation/extinction equilibrium are likely to be fulfilled.

Lobaria pulmonaria is an epiphytic lichen, frequently used as indicator species to identify forest of high conservation priority (Scheidegger and Werth 2009) and woodland ecological continuity questioned (Whittet and Ellis 2013). This species prefers to grow in primeval or old-growth forests in Central Europe, although it is also known from wooded pastures and chestnut orchards in other regions with a more oceanic climate (Rose 1976, 1992; Gauslaa 1994; Jüriado et al. 2012). In spite of the large Holarctic distribution area (Yoshimura 1971), the species is threatened in many European countries (Scheidegger and Werth 2009). Lobaria pulmonaria is known to be sensitive to anthropogenic influence, including air pollution (Rose 1976) and forest management (Rose 1988). Furthermore, abundance, spatial and temporal connectivity of mature and veteran trees, i.e., habitat network dynamics of forest landscapes with old-growth characteristics, may explain the regional distribution and dispersal pattern of the epiphytic lichen L. pulmonaria (Rose 1992; Otalora et al. 2011; Kalwij et al. 2005). Although the species distribution and abundance has frequently been studied in fragmented or partially managed forest landscapes (Fritz et al. 2009; Nascimbene et al. 2013; Otalora et al. 2011), the species natural distribution pattern is largely unknown from reference ecosystems such as large continuous primeval forest areas.

The Uholka-Shyrokyi Luh Mountains (Eastern Carpathians, Ukraine) comprise more than 10,000 ha and are considered the largest primeval beech forest of Europe (Brändli and Dowhanytsch 2003). This area may be regarded as a reference natural ecosystem for the biodiversity assessment, because no anthropogenic or large-scale natural disturbances have been reported during the last centuries (Brändli and Dowhanytsch 2003; Commarmot et al. 2005; Trotsiuk et al. 2012). Data on air pollution of this area is lacking, however it is remote enough from current pollutant sources. The primeval forest of Uholka-Shyrokyi Luh consists of almost pure beech stands (Brändli and Dowhanytsch 2003), which is one of the most suitable host-tree species for L. pulmonaria in continental Europe (Mikryukov 2011; Scheidegger et al. 2012). Thus management disturbances and host-tree impact on the distribution and dispersal characteristics of the L. pulmonaria can be excluded. Alternatively, the focus can be on which topographic and forest-stand factors influence the distribution and dispersal success of the lichen.

In this study we aimed to investigate the distribution, density and reproductive structure of L. pulmonaria in the primeval beech forest landscape of Uholka-Shyrokyi Luh, and to analyze the characteristics of the species' populations in different parts of the reserve. We hypothesized that L. pulmonaria occurs frequently and forms dense populations with a high proportion of fertile individuals in the largest primeval, uneven-aged beech forest of Europe. We also wanted to study (1) which environmental factors shape the occupancy and density of L. pulmonaria in the study region, and (2) which factors explain the density of juvenile and mature vegetatively reproducing, and fertile individuals of $L$. pulmonaria, respectively.

\section{Materials and methods}

Study species

Lobaria pulmonaria is lichen-forming ascomycete, which forms an obligate mutualistic symbiosis with the green alga Dictyochloropsis reticulata. It can reproduce clonally and 
sexually (Dal Grande et al. 2012; Singh et al. 2012). Clonal spread is achieved by symbiotic propagules such as soredia, isidioid soredia or thallus fragments (Scheidegger and Goward 2002). The soredia in L. pulmonaria may develop in "isidioid soredia", when an outer layer of hyphae form a cortex above aggregates of soredia (Büdel and Scheidegger 2008). Heterothallic, sexual reproduction of the fungal symbiont by ascospores is limited to a changing percentage of individuals, which is hypothesized to depend on the availability of mating types (Zoller et al. 1999; Singh et al. 2012), environmental quality (Edman et al. 2008) and developmental stage of the lichen thallus (Denison 2003). Lichen thalli without soralia and isidioid soredia were defined here as juveniles (Honegger and Scherrer 2008; Jüriado et al. 2011), while thalli with isidioid soredia were considered as mature, and with fruit bodies as fertile.

The biology of L. pulmonaria varies depending on part of its distribution range, which contrast in oceanic and continental regions (Coxson et al. 2003; Høistad and Gjerde 2011; Jüriado et al. 2012; Werth et al. 2006). Vegetative dispersal is dominating in this species at the local scale up to $30 \mathrm{~m}$ (Walser 2004), however sexual ascospores are essential for longdistance dispersal (Werth et al. 2006, 2007). Local abundance of this lichen and variation in its generative or vegetative stages are an important population pattern and indicator of individual vitality (Öckinger and Nilsson 2010).

Study area

The study was carried out in the Uholka-Shyrokyi Luh Massif of the Carpathian Biosphere Reserve, which is situated in the south-western part of Ukraine between $48^{\circ} 18^{\prime} \mathrm{N}$ and $23^{\circ} 42^{\prime} \mathrm{E}$ (Fig. 1a). The mountain slopes are covered by almost pure beech forests $(97.3 \%$ of Fagus sylvatica) within two contiguous areas Uholka and Shyrokyi Luh. These forests occupy an area of 10,383 ha, from which 8,500 ha (88\%) are considered primeval forests (Brändli and Dowhanytsch 2003).

The landscape ranges from 400 and 1,500 $\mathrm{m}$ a.s.l., with an anthropogenically influenced timberline at around $1,140 \mathrm{~m}$ a.s.l. The slopes have different aspects and inclinations, ranging from horizontal terraces to steep slopes up to $100 \%$ inclination, with a mean inclination of approx. $50 \%$ (Commarmot et al. 2013). South-facing and less steep slopes at lower altitudes are frequent in the Uholka area, while the Shyrokyi Luh area is more varied (Commarmot et al. 2013). The climate is temperate with a mean annual temperature of $+8{ }^{\circ} \mathrm{C}$ and an annual precipitation of $1,130 \mathrm{~mm}$, measured in Uholka at altitude of $430 \mathrm{~m}$ (Bursak 1997; Commarmot et al. 2013). In the Shyrokyi Luh, the annual temperatures are slightly lower than in the Uholka (Brändli and Dowhanytsch 2003).

The beech forest stands are characterized by an uneven-aged and multi-layered structure. The canopy is mostly closed, making forest floristically homogeneous (Bursak 1997; Commarmot et al. 2005), with little local differentiation of the epiphytic lichens (Dymytrova et al. 2014). The mean age of beech trees in the upper canopy cored in the Uholka part is over 200 years, with a maximum of 550 years identified by age estimation methods (Trotsiuk et al. 2012). There are no relations between size of the tree and its age in the Uholka-Shyrokyi Luh beech forest (Commarmot et al. 2013).

Sampling design and variables measured

Selection of spatial scale for analyses

During 2009-2011 we studied the occupancy of Lobaria pulmonaria on 314 forestinventory plots of 0.05 ha each within a perimeter of 10,282 ha. Clusters of two sample 


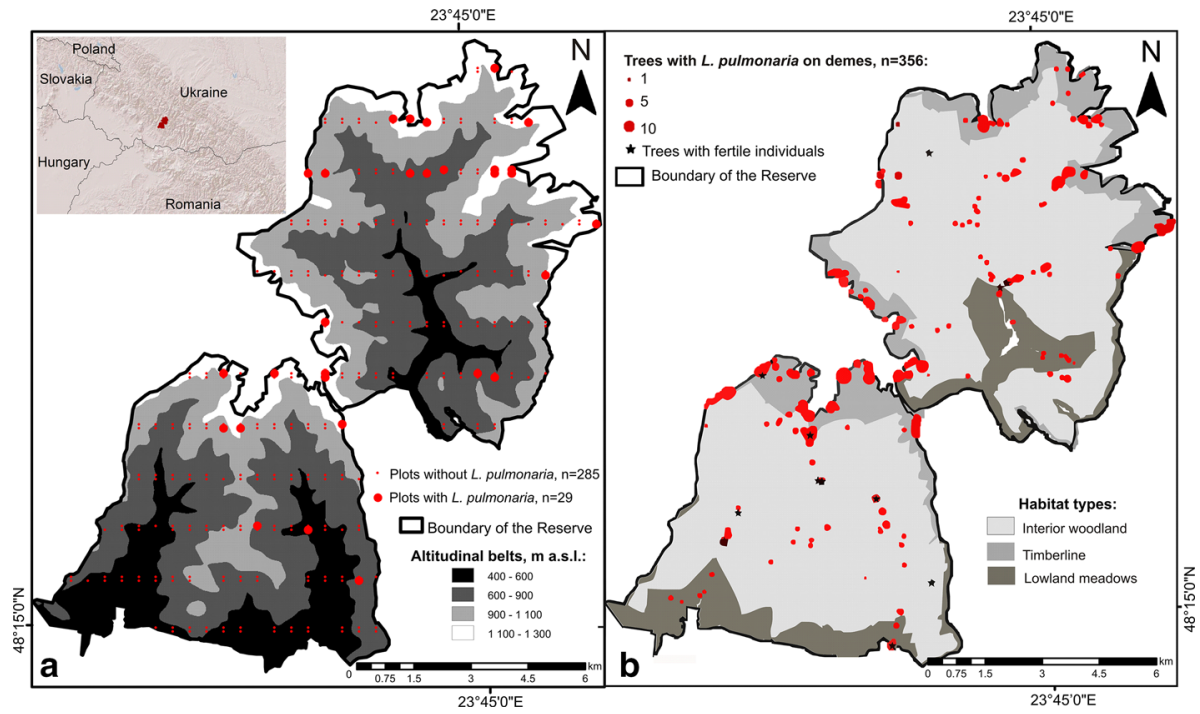

Fig. 1 a Location of Uholka-Shyrokyi Luh in Europe, the area of primeval beech forest is shown with altitudinal belts. The forest inventory plots established are shown as red dots $(n=314)$, depending on presence of trees with L. pulmonaria on plot. b Main habitat types within reserve are shown as gradation of grey. The demes harbouring trees with L. pulmonaria are shown by red dots $(n=356)$, depending on density of trees with $L$. pulmonaria per deme. The trees with fertile individuals marked with asterisk $(n=14)$. (Color figure online)

plots each were arranged on a systematic grid of $445 \mathrm{~m} \times 1,235 \mathrm{~m}$ with a distance of $100 \mathrm{~m}$ between the plots of one cluster (Fig. 1a). This dense net of plots (Fig. 1a) covered the total altitudinal range and all topographic elements within the perimeter of the inventory (Commarmot et al. 2013). We also assessed the whole forest area for L. pulmonaria occupancy and density outside the inventory plots. This search for $L$. pulmonaria over the entire study perimeter allowed an intensive screening of the whole area, covering the plots and the area in between, and thus a near complete sampling of the trees with $L$. pulmonaria. The trees harbouring this lichen species were scattered over the entire forest massif. We measured coordinates of each tree with $L$. pulmonaria with a GPSmap 62st (GARMIN, Bucher and Walt, St.-Blaise, Switzerland). To assess the most effective deme (Werth et al. 2006) size for density analysis, we made a preliminary test (Fig. 2).

Trees with L. pulmonaria were plotted in ArcGis.10.1 (ESRI, http://www.esri.com/ software/arcgis), and then the functions Grid Index Features and Spatial Join were used to group trees with lichen into demes with different sizes $(0.05,0.1,0.5,1,5,10,25,50$ and $100 \mathrm{ha}$ ), as implemented in ArcGis.10.1. Generalized linear models (GLMs) were used to analyze mean number of trees with $L$. pulmonaria per demes of different sizes. This analysis show that number of trees with $L$. pulmonaria per deme increased on one tree, when enlarging a deme on each 2 ha (Fig. 2a). Demes up to 1 ha had no significant effect on number of trees with L. pulmonaria (Fig. 2a, b) and we therefore selected 0.05 ha (square with $22.4 \mathrm{~m}$ side) as preferred size to study occupancy and density of L. pulmonaria in the primeval beech forest. The scale of 0.05 ha was also used in intensive forest inventory of Uholka-Shyrokyi Luh area (Commarmot et al. 2013), because spatial autocorrelation within such clusters found to be very small (Commarmot et al. 2013; Lanz 2011). Additionally, the 

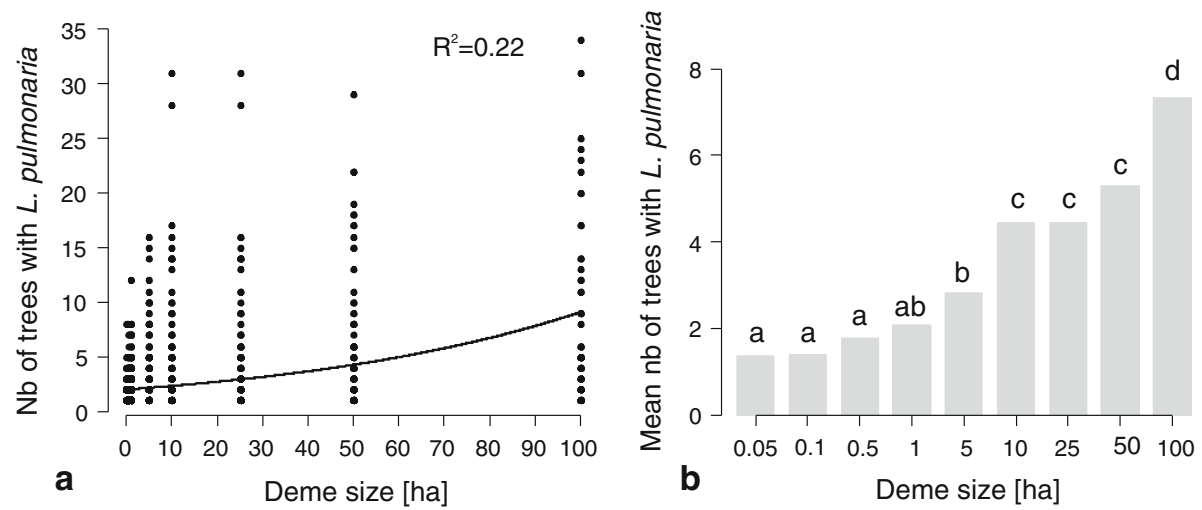

Fig. 2 Number of trees with L. pulmonaria per deme depends on deme size in the primeval beech forest of Uholka-Shyrokyi Luh. a Scatterplot and GLM fit line MacFadden's pseudo $R^{2}=0.22, p \leq 0.001$. b Barplot showing mean number of trees with L. pulmonaria on the plots of different size. The letters above bars show differences in the level of means based on Tukey-Kramer HSD $t$-test

distance up to $30 \mathrm{~m}$ is considered as a limit for vegetative dispersal of L. pulmonaria (Werth et al. 2006), and genetic diversity within such a small clusters supposed to be high in an oldgrowth forests (Scheidegger et al. 2012).

Taking into account result of our preliminary analysis, all the following analyses were performed on a scale of 0.05 ha within perimeter 10,282 ha.

\section{Occupancy}

Occupancy, or probability of occurrence, was understood as presence/absence of trees with of L. pulmonaria on the 314 forest inventory plots (Commarmot et al. 2013). They cover the entire forest reserve area with an altitudinal gradient from 458 to $1,269 \mathrm{~m}$ a.s.l. The degree of crown cover in all layers of the stand varied between 15 and $100 \%$ with a mean of $76 \%$. The average tree diameter at breast height per plot varied between 11 and $114 \mathrm{~cm}$ with a mean of $35 \mathrm{~cm}$, however the highest density of trees is in the smallest diameter class, with a second small peak in the mid-diameter range (Commarmot et al. 2013). A total of 222 plots $(71 \%)$ were situated in the core zone of the reserve, while 72 plots $(23 \%)$ were located in the buffer zone, 16 plots $(5 \%)$ within the regulated protection zone, and 4 plots $(1 \%)$ belonged to the anthropogenic landscapes (Commarmot et al. 2013). In order to study the distributional pattern of L. pulmonaria in the different parts of the primeval forest we distinguished three habitat types, which were related to functional zoning of the reserve: (1) timberline forest stands, close to subalpine meadows (pooled buffer and anthropogenic landscapes zones at the forest margin above $900 \mathrm{~m}$ ), lowland meadows (pooled buffer and anthropogenic landscapes zones along the rivers or streams below $900 \mathrm{~m}$ ), and interior woodland stands (include continuous forest within core zone of the reserve and zone of regulated protection; Fig. 1b). The buffer and anthropogenic landscape zones are traditionally used as cattle pasturing, what affected tree growth along the timberline nearly at 1,140 m a.s.l. (Brändli and Dowhanytsch 2003). The regulated protection zone (Brändli and Dowhanytsch 2003) comprises $50 \mathrm{~m}$ width buffers on both sides of the main roads through the core zone, where e.g., cutting of trees fallen across the paths is allowed. The topographic and forest-stand variables were measured during the 
Table 1 List of variables used for L. pulmonaria occupancy study (314 systematically arranged plots)

\begin{tabular}{ll}
\hline Variables & Types \\
\hline Topographic & \\
$X$ and $Y$ coordinates (UTM) & Continuous \\
Altitude a.s.l. (m) & Continuous \\
Slope aspect (gon) & Continuous \\
Slope inclination (\%) & Continuous \\
Relief [flat area, foot slope (depressions), middle slope, hilltop] & Nominal \\
Forest-stand & \\
Canopy cover, degree of crown cover in the upper, medium and lower layers of the stand & Continuous \\
$\quad(\%)$ & \\
Canopy closure in upper layer (closed, loose, scattered) & Ordinal \\
Size of gap above sample plot center (categories in $\mathrm{m}^{2}$ : from totally open to close) & Ordinal \\
Stem density (per ha on the plot) & Continuous \\
Mean tree diameter (cm) & Continuous \\
Deadwood (m ${ }^{3} /$ ha) & Continuous \\
Response & \\
Trees with $L$. pulmonaria (presence/absence) & Binomial \\
\hline
\end{tabular}

inventory of the primeval beech forest structure, while slope aspect and inclination of the plots were extracted from a digital elevation model of the Carpathian Biosphere Reserve (Table 1; Commarmot et al. 2013).

\section{Density}

The density of L. pulmonaria was understood as number of trees with L. pulmonaria per deme (percent of trees with lichen per total number of trees), and was evaluated for 483 trees belonging to 356 demes. The lichen thalli (interpreted here as individuals) were collected up to 5-6 $\mathrm{m}$ on the trees using an avalanche probe (Black Diamond, Reinach, Switzerland) and along the whole trunk on lying trees. The following parameters were assessed in the field or extracted from the digital elevation model (Commarmot et al. 2013) for each tree with L. pulmonaria: coordinates, altitude, tree parameters (species, diameter at breast level, and vitality), relief characteristics (valley, slope or ridge; slope aspect and inclination), and habitat types (Table 2). Host tree vitality was classified as standing trees (living or dead) and lying trees (deadwood).

\section{Developmental stages of L. pulmonaria}

Developmental stages of L. pulmonaria were expressed as number of juvenile, mature or fertile individuals per deme (percent of those stages per total number of specimens; Table 2). Those stages were assessed for 356 demes, as for lichen density evaluation, but take into account 1,520 lichen individuals assessed. In average three thallus fragments (considered here as individuals) per each tree were assessed, preferably from different aspects of the trunk. The following parameters were measured at the individuals level: height and aspect on the trunk, developmental stage (juvenile, mature, fertile), and we 
Table 2 List of variables used for the study of density the of trees with L. pulmonaria, and its different developmental stages (356 demes, 483 trees, 1,520 individuals of L. pulmonaria)

\begin{tabular}{|c|c|}
\hline Variables & Types \\
\hline \multicolumn{2}{|l|}{ Topographic } \\
\hline$X$ and $Y$ coordinates (UTM) & Continuous \\
\hline Altitude a.s.l. (m) & Continuous \\
\hline Slope aspect $\left(^{\circ}\right)$ & Continuous \\
\hline Slope inclination $(\%)$ & Continuous \\
\hline Relief (valley, slope, ridge) & Nominal \\
\hline Distance from the stream or river $(\mathrm{m})$ & Continuous \\
\hline \multicolumn{2}{|l|}{ Forest-stand } \\
\hline Host tree diameter $(\mathrm{cm})$ & Continuous \\
\hline Host tree vitality (dead lying, dead standing, recently fallen, living standing) & Nominal \\
\hline Habitat type (interior woodland, timberline, lowland meadow) & Nominal \\
\hline \multicolumn{2}{|l|}{ Lichen characteristics } \\
\hline Sample height on the trunk (m) & Continuous \\
\hline Sample exposition on the trunk $\left(^{\circ}\right)$ & Continuous \\
\hline Fertility (fertile, sterile) & Nominal \\
\hline Thallus developmental stage (juvenile, sorediate, mature) & Nominal \\
\hline Plectocarpon lichenum infection (present, absent) & Nominal \\
\hline \multicolumn{2}{|l|}{ Responses } \\
\hline Trees with Lobaria pulmonaria per deme (\%) & Continuous \\
\hline Juvenile individuals per deme $(\%)$ & Continuous \\
\hline Mature individuals per deme (\%) & Continuous \\
\hline Fertile individuals per deme $(\%)$ & Continuous \\
\hline
\end{tabular}

Lichen characteristics were fixed for each of 1,520 L. pulmonaria individuals

visually inspected for an infection with the host-specific fungal parasite Plectocarpon lichenum (Table 2).

Statistical analyses

Statistical analyses were performed with $R$ (R Development Core Team 2011) and considered significant when $p<0.05$. The distances of trees with lichen from the nearest stream were square-root-transformed. The host tree diameters were log-transformed. The slope aspect was arcsine-transformed and the exposition expressed as Eastness and Northness (Roberts 1986). The relationships between the presence or absence of L. pulmonaria on forest inventory plots with topographic and forest-stand factors were tested with GLMs using a "binomial" model family. Density of L. pulmonaria, and its developmental stages per deme, as response to topographic and forest-stand factors, were tested with GLM using "gaussian" or "poisson" model families. The best models were selected on the basis of Akaike information criterion (1974) using "both" directions as implemented in mass package. This approach allows to drop out multicollinear variables with high information inflation factor (VIF). Densities of plots with and without L. pulmonaria were visualized with sm.density.compare function in sm package, and density of total trees with L. pulmonaria per deme with density function in mixtools package. 
Analyses of variance ANOVA, with following Tukey-Kramer HSD $t$-tests, were applied to examine relations between continuous responses and categorical variables, i.e., number of trees with L. pulmonaria per deme with different spatial scales, number of trees with $L$. pulmonaria per deme with habitat types, number of individuals of different developmental stages with categories of tree vitality.

All maps were drawn in ArcGis.10.1, which was used also to calculate the distances of the trees with lichen from the nearest stream.

\section{Results}

\section{Occupancy of L. pulmonaria}

We found trees with L. pulmonaria on $29(9.29 \%)$ of the total 314 forest-inventory plots (Table 3; Fig. 1a). Within these plots we found a total of 42 trees of Fagus sylvatica with lichen.

The occupancy of L. pulmonaria in the Uholka-Shyrokyi Luh primeval forest area significantly depended on altitude above sea level (Table 4; Fig. 3a, b) and canopy cover (Table 4; Fig. 3c, d).

We found that the altitudinal distribution of the plots with L. pulmonaria have a bimodal pattern, whereas the plots without lichen showed an unimodal distribution (Fig. 3b, d). The plots without $L$. pulmonaria were distributed over a wide altitudinal range (458-1,269 m a.s.1.), with a mean at $850 \mathrm{~m}$ a.s.1., while plots with $L$. pulmonaria were concentrated around 765 and 1,170 m, respectively (Fig. 3b). Analogously, the mean canopy cover on the forest inventory plots without L. pulmonaria was $75.5 \%$, while $72.4 \%$ of the plots with L. pulmonaria were concentrated in loose stands and $26.3 \%$ in scattered stands (Fig. 3d).

\section{Density of L. pulmonaria}

We analyzed 483 trees carrying a total of 1,520 L. pulmonaria individuals, which were scattered on 356 demes (Table 3; Fig. 1b) between 392 and 1,307 m a.s.l. Trees with $L$. pulmonaria were equally distributed among the two forest massifs $\left(\chi^{2}=2.7, p=0.1^{\mathrm{ns}}\right.$, Table 3). However the number of individuals was slightly higher in Shyrokyi Luh area $\left(\chi^{2}=5.6, p=0.018^{*}\right.$, Table 3$)$. Lobaria pulmonaria was growing predominantly on 471 trees of Fagus sylvatica and only occasionally on Acer pseudoplatanus (12 trees) in the Uholka-Shyrokyi Luh primeval beech forest.

Table 3 Frequency of L. pulmonaria in the primeval beech forest of Uholka-Shyrokyi Luh

\begin{tabular}{llccc}
\hline Part of the area & $\begin{array}{l}\text { Nb of forest inventory } \\
\text { plots with } \text {. pulmonaria/total }\end{array}$ & $\begin{array}{l}\text { Nb of } \\
\text { demes }\end{array}$ & $\begin{array}{l}\text { Nb of } \\
\text { trees }\end{array}$ & $\begin{array}{l}\text { Nb of } \\
\text { individuals }\end{array}$ \\
\hline Uholka & $8 / 145$ & 158 & 224 & 715 \\
Shyrokyi Luh & $21 / 169$ & 198 & 259 & 805 \\
Interior woodland & $19 / 230$ & 122 & 151 & 449 \\
Timberland & $8 / 42$ & 189 & 282 & 159 \\
Lowland meadows & $2 / 42$ & 45 & 50 & 912 \\
Total & $29 / 314$ & 356 & 483 & 1,520 \\
\hline
\end{tabular}


Table 4 Best fitting general linear model (GLM), which explain the occupancy of L. pulmonaria as a function of topographic and forest-stand variables collected on 314 forest inventory plots in the primeval beech forest of Uholka-Shyrokyi Luh

\begin{tabular}{lccc}
\hline Variables & Estimates & SE & $z$ \\
\hline$R^{2}=0.23$ & & & $-3.34^{* * *}$ \\
Intercept & -5.36 & 1.6067 & $4.94^{* * *}$ \\
Altitude a.s.l. & 0.006 & 0.0013 & $-2.97 * *$ \\
Canopy cover & -0.04 & 0.0138 & \\
\hline
\end{tabular}

$R^{2}$ MacFadden's pseudo $R^{2}, z$ Wald's statistic

Significant variables are indicated with $* * *(p \leq 0.001)$ and $* *(p \leq 0.01)$

The total altitudinal distribution of L. pulmonaria individuals showed a clear bimodal pattern with one group being concentrated around $690 \mathrm{~m}$ a.s.l. and the other around 1,188 $\mathrm{m}$ a.s.l. (Fig. 4a). The majority of trees harbouring L. pulmonaria (nearly $80 \%$ ) were above $900 \mathrm{~m}$ a.s.l. Another part of the trees with L. pulmonaria was found very scattered in the lowlands below $900 \mathrm{~m}$ (Fig. 4a).

The density of trees with L. pulmonaria on 356 demes found to be related to altitude a.s.l., habitat types and slope aspect (Table 5; Fig. 4). The density increases with altitude and was highest at the timberline with scattered tree stands, where it reached 8 trees/per
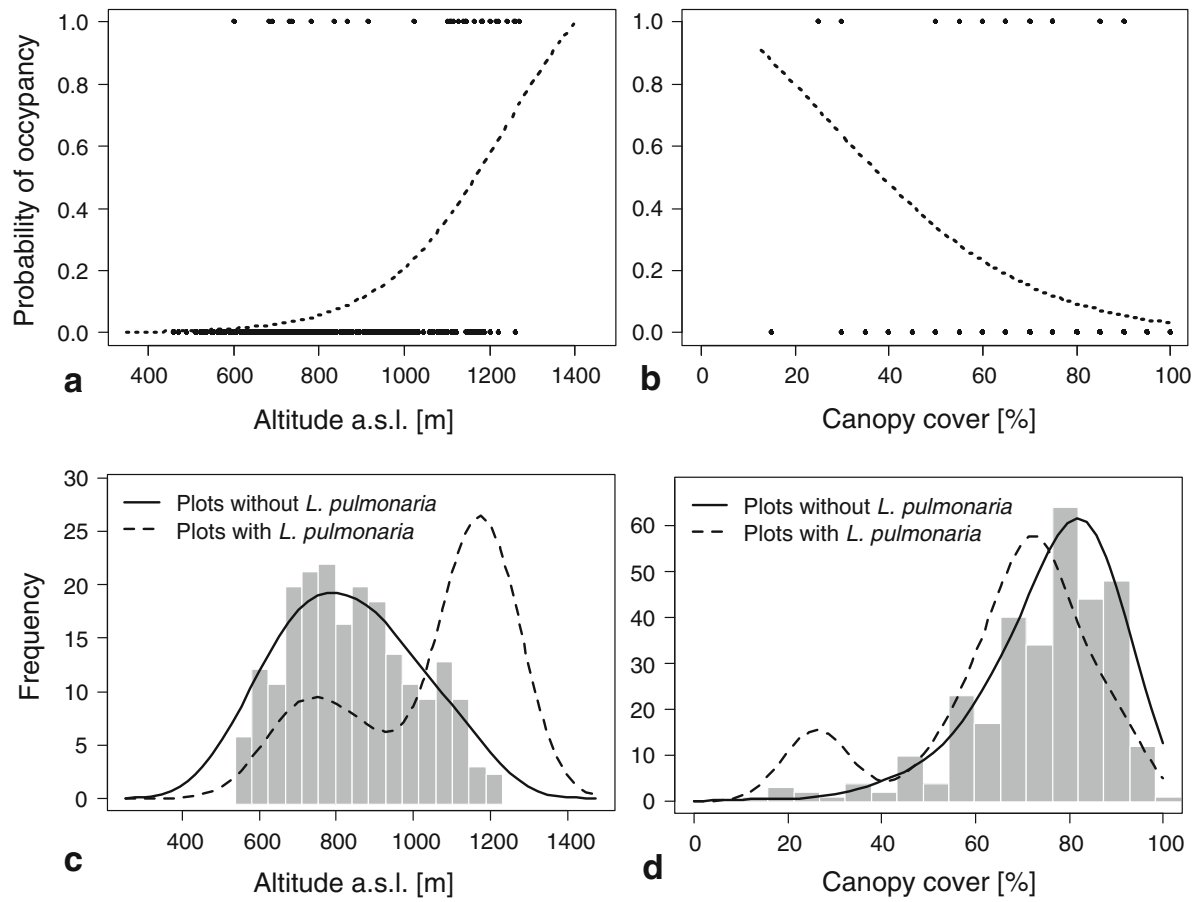

Fig. 3 Distribution of variables, which explain presence of $L$. pulmonaria on the studied plots $(n=314)$ in the Uholka-Shyrokyi Luh: a, c altitude a.s.l., b, d canopy cover. Compared densities show unimodal distribution for the plots without L. pulmonaria (c, d, solid line), and bimodal for the plots with $L$. pulmonaria (c, d, dashed line). Grey histogram show total distribution of plots 

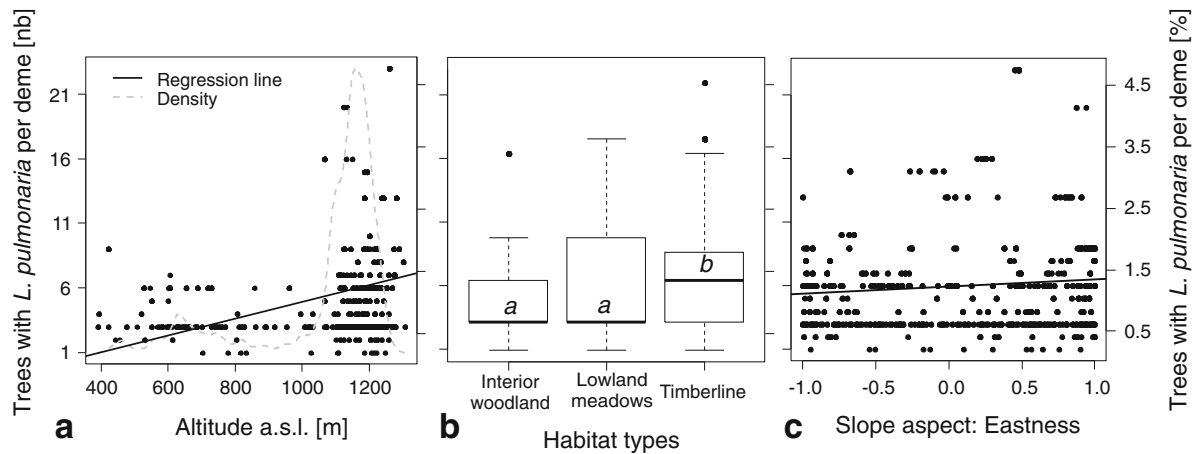

Fig. 4 Distribution of variables, which explain density of L. pulmonaria on the studied demess $(n=356)$ in the Uholka-Shyrokyi Luh: a altitude a.s.l., b habitat types, and c slope aspect. Solid lines show linear regression trends. The dashed density line show bimodal altitudinal distribution of trees with L. pulmonaria. Boxplots show mean number of trees with L. pulmonaria in different habitat types. The letters above the mean line show differences in the level of means based on Tukey-Kramer HSD $t$-test

deme or $1.5 \%$ of the total trees which were colonized with L. pulmonaria (Fig. 4a, b). Trees with $L$. pulmonaria reached a higher density at the eastern slopes of the mountains (Fig. 4c).

The mean height where L. pulmonaria was growing at the trunk of the host tree was $2.6 \mathrm{~m}$, and this value was not different between two forest massifs of Uholka and Shyrokyi Luh $\left(\chi^{2}=0.03, p=0.8^{\text {ns }}\right)$ and mean height was negatively correlated with altitude a.s.l. (Fig. 5a). The mean height of L. pulmonaria on the trunk also varied among different habitat types within the reserve and was typically growing at $4 \mathrm{~m}$ within interior woodland, at $3.5 \mathrm{~m}$ in the lowland meadows, and at $2 \mathrm{~m}$ at the timberline (Fig. $5 \mathrm{~b}$ ).
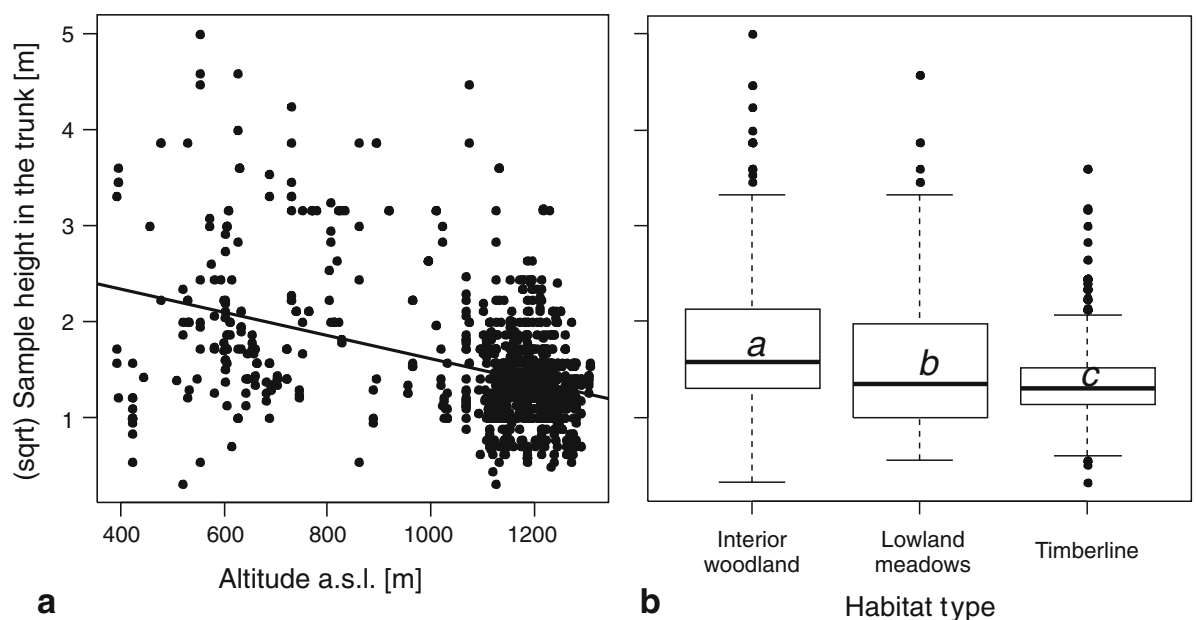

Fig. 5 Variation of sample height on the trunk with altitude. a Negative Spearman's rank correlation $R=-0.43^{* * *}$. b Boxplot showing mean sample height on the trunk in different habitat types. The letters above mean line show differences in the level of means based on Tukey-Kramer HSD $t$-test 
Fig. 6 Differences in frequency of L. pulmonaria within thallus developmental stages $(n=1,520)$

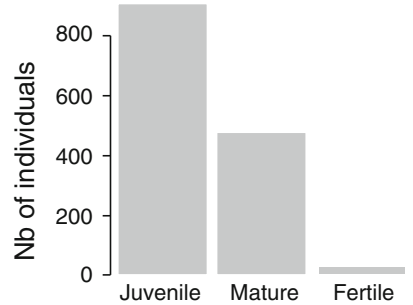

\section{Developmental stages of L. pulmonaria}

Most thalli were lacking any vegetative propagula (911 individuals or $59.86 \%$ ) or juvenile, 134 individuals $(8.80 \%)$ were sorediate and another 480 thalli developed isidioid soredia (31.54\%), and considered as mature in our analysis (Fig. 6). We found only 39 fertile individuals of $L$. pulmonaria $(2.56 \%$ of total) in the entire study area; they were concentrated on 14 trees (11 trees of Fagus sylvatica and three trees of Acer pseudoplatanus; Fig. 1b, 6). The fruit bodies were found on individuals, which developed isidioid soredia (15 specimens, $38.5 \%$ ), soredia (11 specimens, $28.2 \%$ ), but on 13 fertile specimens $(33.3 \%)$ no vegetative propagules appeared.

The individuals of different developmental stages had similar or opposite trends with different environmental variables (Table 5; Fig. 7). The density of trees with L. pulmonaria per deme positively correlated with all developmental stages, and all developmental stages were more common on eastern slopes of the mountains (Fig. 7a, b). Altitude a.s.l. positively affected the density of juvenile and mature individuals, but negatively influenced the density of fertile individuals (Fig. 7c). Fertile individuals were concentrated on terraces, while the densities of the other developmental stages were not influenced by inclination (Fig. 7e). Juvenile individuals were more abundant on trees of smaller diameters, and mature preferred trees with bigger sizes, while this factor was not significant for fertile individuals (Fig. 7d). Juvenile individuals occurred equally on trees of different vitality, while mature individuals were more frequent on dead standing trees (Table 5; Fig. 7f). Fertile individuals were always found on living trees.

Fertile individuals were equally distributed among the two forest massifs (Fig. 1b) and their presence correlated with a high density of $L$. pulmonaria per deme and was concentrated at intermediate elevations, eastern aspects and horizontal terraces (Table 5; Fig. 7a-d).

\section{Discussion}

This is the first assessment of Lobaria pulmonaria populations in the largest primeval beech forest in Europe, based on a non-stratified plot network of over 10,000 ha (Commarmot et al. 2013). Contrary to our expectations of high frequency and population density of L. pulmonaria in a primeval beech forest, L. pulmonaria was found on less than $10 \%$ of the plots, and a high density of trees with $L$. pulmonaria was only found at the timberline. Instead, we found that the distribution of L. pulmonaria in this primeval beech forest had a bimodal pattern related to altitude a.s.l. and canopy openness. Also contrary to our expectations the developmental stages were dominated by juvenile, non-reproducing individuals and sexual reproduction was found to be extremely rare in the study area. 
Table 5 Best fitting general linear models (GLM), which explain the density of L. pulmonaria and its dispersal strategies success per deme in terms of the topographic and forest-stand variables

\begin{tabular}{lccr}
\hline Parameter/responseldependent variables & Estimates & SE & $t$ \\
\hline $\begin{array}{l}\text { Density. Response trees with Lobaria pulmonaria per deme }(\%) \\
R^{2}=0.09, F=33.4 * * *\end{array}$ & & & \\
Intercept & 0.4998 & 0.1352 & $3.70^{* * *}$ \\
Habitat (timberline) & 0.3444 & 0.0678 & $5.07 * * *$ \\
Slope aspect (Eastness) & 0.1337 & 0.0333 & $4.01 * * *$ \\
Altitude a.s.l. & 0.0005 & 0.0001 & $3.28^{* *}$
\end{tabular}

Juvenile individuals. Response trees with juvenile individuals per deme (\%) $R^{2}=0.54, F=542.7 * * *$

$\begin{array}{lrrr}\text { Intercept } & 0.1897 & 0.0186 & 10.18^{* * * *} \\ \mathrm{Nb} \text { of trees with L. pulmonaria per deme } & 0.0334 & 0.0009 & 38.18^{* * *} \\ \text { Altitude a.s.l. } & 0.0001 & 0.0000 & 4.07 * * * \\ \text { Host tree diameter } & -0.0005 & 0.0002 & -3.18^{* *}\end{array}$

Mature individuals. Response trees with mature individuals per deme (\%) $R^{2}=0.29, F=91.85^{* * *}$

$\begin{array}{lccc}\text { Intercept } & 0.0448 & 0.0308 & 1.46 \\ \mathrm{Nb} \text { of trees with L. pulmonaria per deme } & 0.0257 & 0.0011 & 22.04 * * * \\ \text { Host tree vitality (dead standing) } & 0.0887 & 0.0244 & 3.63^{* * *} \\ \text { Host tree diameter } & 0.0007 & 0.0002 & 3.31 * * * \\ \text { Slope aspect (Eastness) } & -0.0179 & 0.0073 & -2.47 *\end{array}$

Fertile individuals. Response trees with fertile individuals per deme (\%) $R^{2}=0.23, F=101.20 * * *$

$\begin{array}{lrrr}\text { Intercept } & 0.0922 & 0.0174 & 5.29 * * * \\ \text { Nb of trees with L. pulmonaria per deme } & 0.0134 & 0.0008 & 16.56^{* * *} \\ \text { Slope aspect (Eastness) } & 0.0285 & 0.0049 & 5.83 * * * \\ \text { Altitude a.s.l. } & -0.0001 & 0.0000 & -5.70 * * * \\ \text { Slope inclination }(\%) & -0.0027 & 0.0004 & -7.15 * * *\end{array}$

Data includes 483 trees with L. pulmonaria found on and/or between forest inventory plots in the primeval beech forest of Uholka-Shyrokyi Luh

$R^{2}$ determination coefficient, $t$ t-statistic

Significant variables are indicated with $* * *(p \leq 0.001), * *(p \leq 0.01)$ and $*(p \leq 0.05)$

\section{The bimodal distribution of Lobaria pulmonaria}

We showed that altitude is the main factor determining the bimodal distribution of $L$. pulmonaria in the Uholka-Shyrokyi Luh primeval forest (Tables 4, 5; Figs. 3a, b, 4a). A bimodal altitudinal distribution for L. pulmonaria has been documented in other parts of Ukrainian Carpathians (Kondratyuk et al. 1998), Switzerland (Stofer et al. 2008) and southeastern Europe (Scheidegger et al. 2012).

The decreasing air temperature and increasing solar/UV-radiation with altitude are generally known climatic trend (Barry 1981; Körner 2007). The solar radiation varies little along the relatively short altitudinal gradient in our study region, and altitude not influences homogeneous forest structure within the primeval beech forest of Uholka-Shyrokyi Luh (Commarmot et al. 2013). Nevertheless, the probability to found trees with 

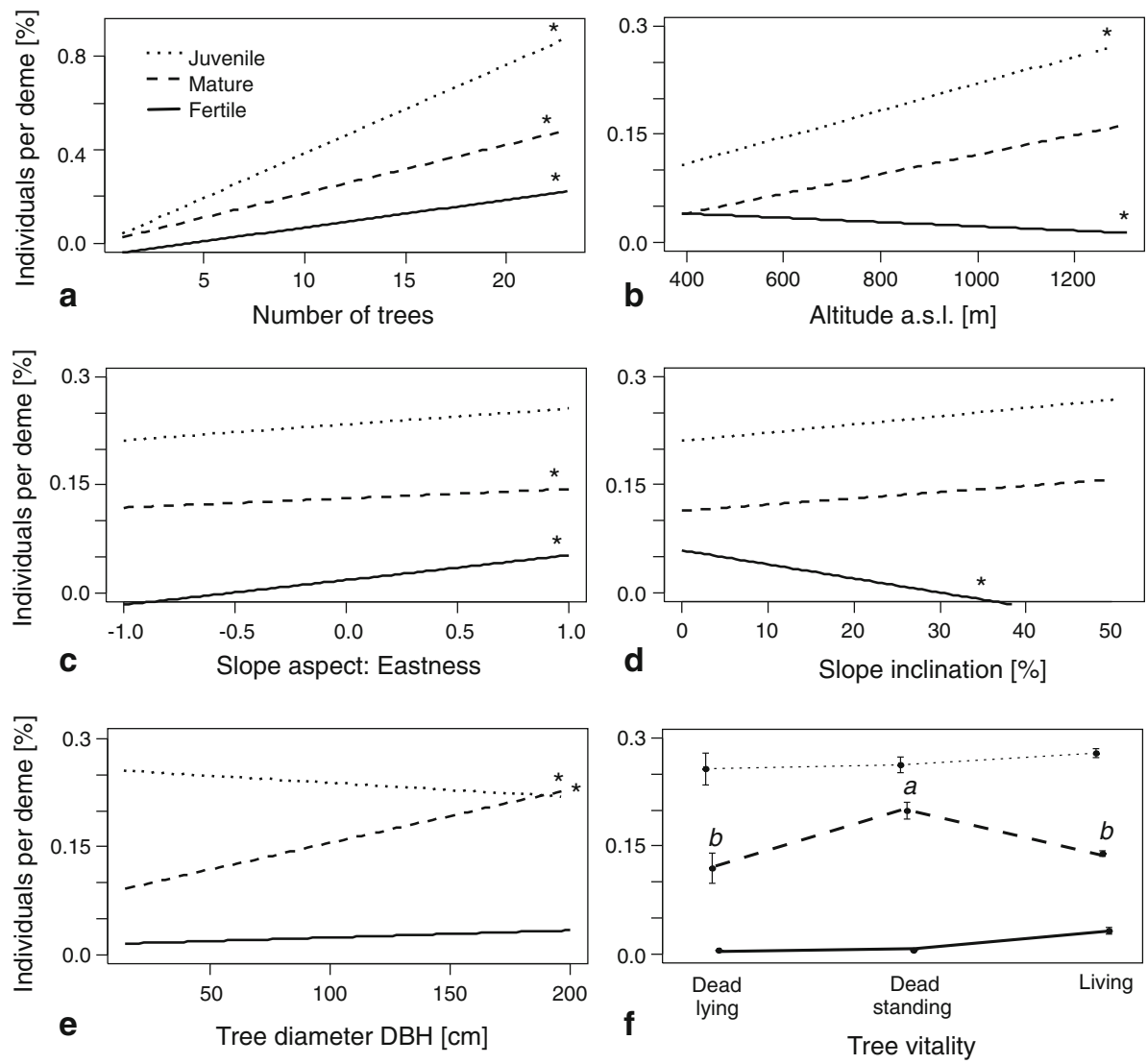

Fig. 7 The trends of variables, which explain density of L. pulmonaria per deme in a primeval beech forest of Uholka-Shyrokyi Luh: a-e linear regressions showing influence of number of trees per deme, altitude a.s.l., slope aspect and inclination, and host tree diameter. f Level of means between trees of different vitality. The letters above mean show differences in the level of means based on Tukey-Kramer HSD $t$-test. Developmental stages shown with different lines: juvenile with dotted, mature with dashed, and fertile with solid line. Developmental stages, which influence significant effect of tested variable, are shown with asterisks

L. pulmonaria is very low within forest stands with closed canopy along the entire altitudinal gradient, but the species was more frequently found between stands with loose or scattered canopy at higher altitudes (Fig. 3).

The lichen was most abundant along the timberline, than in the lowland meadows and interior woodland stands (Fig. 4b). A similar trend was found in the study region for species richness of epiphytic lichens within forest stands of different canopy closure and elevations (Dymytrova et al. 2014). Thus we conclude that both, altitude and canopy closure explain the bimodal distributional pattern of L. pulmonaria occupancy and density in the primeval beech forest. In addition to temperature gradients and light availability, non-linear gradients in air humidity among these habitats are hypothesized to explain the different lichen occupancy/density. Mountain ridges at timberline in the forest of UholkaShyrokyi Luh have a frequently fluctuating air humidity while the bottom of the slopes or valleys have more constant, relatively high humidity. 
Habitat shift under dense canopy

Most of the lichen individuals grow on trees of small or mid-diameter classes, as most of the trees in the Uholka-Shyrokyi Luh lays in this diameter range (Commarmot et al. 2013). We showed that tree diameter did not affect the presence or total density of L. pulmonaria (Tables 4, 5), but it is essential for the density of juvenile and mature individuals (Table 4; Fig. 7). The host trees of smaller diameters of are often lacking microstructural diversity such as bark crevices and bryophyte patches, which may facilitate high lichen abundance. Similar trends of occupancy on trees with various diameters, including small, has been found for the sites of L. pulmonaria with optimal climate and habitat conditions (Carlsson and Nilsson 2009; Hakulinen 1964; James et al. 1977; Wolseley 1991). However many studies stated that old/large trees are more suitable for L. pulmonaria ( $\mathrm{Gu}$ et al. 2001; Gustafsson et al. 1992; Mikhailova et al. 2005; Öckinger et al. 2005).

We found that L. pulmonaria prefers relatively open stands in the generally dense stands of the primeval beech forest of Uholka-Shyrokyi Luh (Fig. 3b, d). In lowland demes the lichen grows relatively high up at the tree trunk (Fig. 5), where more light is available and air humidity is still relatively high because of the topographic situation at the bottom of valleys. Obviously, the difference in microclimatic parameters, which are co-dependent with altitude, did not affect the beech forest stands which showed an uneven-aged structure at small spatial scales (Commarmot et al. 2005; Trotsiuk et al. 2012). However, the architecture of forest stands affects local temperature, solar radiation and air humidity, which may differ strongly from standard meteorological data (Körner 2007). The epiphytic lichen L. pulmonaria tends to grow either in habitats with loose or scattered canopy (Fig. 3b, d) where it grows at relatively low parts of the trunks, however the species' light requirements require a relatively high position at host tree trunk (Fig. 5) in stands with a higher canopy closure as it is generally found at lower altitudes in the study region. Low light availability at sites with $L$. pulmonaria has been reported to be limiting the establishment of diaspores (Hilmo et al. 2011; Jüriado et al. 2011). Under otherwise favourable climatic conditions the species is known to grow best in habitats with relatively high light availability (Jüriado et al. 2012; Pannewitz et al. 2003).

Our data revealed habitat shift (Schoener 1975) of L. pulmonaria between more open stands at highland timberline, where the mean height at the trunk was found at $2 \mathrm{~m}$, and under more dense canopy in the interior woodland the preferred height at the trunk was $4 \mathrm{~m}$ (Fig. 5b). This habitat shift enables L. pulmonaria to select suitable habitats where light availability and humidity are the main limiting factors. Thus, L. pulmonaria can profit from higher air humidity close to the ground in the places where light is available down to the lower part of the trunk. In contrary, L. pulmonaria has to colonize higher parts of the trunk in places where light availability is limited. However, this is only possible under topographic situations where air humidity is high enough to allow for prolonged physiological activity, i.e., along the bottom of the valleys, but not slopes. The habitat shift described for L. pulmonaria corroborates the law of relative habitat constancy (Breckle 2002), which has previously been confirmed for various lichen species and their habitats, including xerothermic saxicolous species (Poelt 1987; Scheidegger 1991).

\section{Dispersal strategies}

We found mature individuals tending to grow on slopes of eastern exposition (Fig. 7b), what also typical for total density of trees with L. pulmonaria in the massive (Fig. 4c). Mature individuals prefer trees with large diameter (Fig. 7d), which are often dead 
standing (Fig. 7f). This reflects long-lasting growth and local spread of L. pulmonaria thalli on "veteran" trees. Mature individuals are effective for vegetative dispersal, which is considering as a dominating strategy for dispersal of L. pulmonaria (Öckinger et al. 2005; Widmer et al. 2012).

Our analysis showed that fertile individuals were more frequent on eastern slopes and flat terraces, always on living trees and distributed in intermediate altitudes, mean at $850 \mathrm{~m}$, and occurred mainly in the interior woodland stands (Figs. 1b, 7). This altitude correspond to canopy cover of $75.5 \%$ (data of forest inventory), which is higher compared to L. pulmonaria demes growing between loose canopy $(72.4 \%)$ and scattered canopy $(26.3 \%)$. This may indicate that the formation of apothecia requires sheltered places in the forest under the climatic conditions of the study region. In other regions with more humid climate, e.g., at the west coast of Scotland (Rose 1976, 1992), apothecia can also be formed on isolated trees where the lichen is exposed to considerably higher light availability.

Furthermore, the formation of apothecia in the heterothallic species L. pulmonaria (Singh et al. 2012; Zoller et al. 1999) depends on the availability of suitable mates belonging to either of two mating types and on optimal growth conditions, which is often reflected by a high abundance (Mikryukov et al. 2010; Scheidegger 1995). In our study region apothecia were produced by thalli belonging to different developmental stages, including thalli without vegetative propagules, which are usually interpreted either as juvenile or suppressed (Honegger and Scherrer 2008).

Vegetative dispersal capacity has been reported as the most important factor in limiting the local distribution of L. pulmonaria (Öckinger et al. 2005), and the distance of $30 \mathrm{~m}$ is optimal for the vegetative propagation of L. pulmonaria (Werth et al. 2006). However, the trees with L. pulmonaria are scattered in the studied area at higher distances (Fig. 1b). Furthermore, relatively low percentage of mature and fertile individuals make local dispersal even more complicated. We suggest the L. pulmonaria supports dispersal within populations in a close relation to natural gap dynamic of the forest, i.e., fallen trees are a vector for lichen, which allow moving for a new host trees up to $30 \mathrm{~m}$ and more.

Low frequency of reproducing individuals

The juvenile thalli without any vegetative propagules $(59.86 \%)$ dominated in the studied populations of L. pulmonaria in the Uholka-Shyrokyi Luh primeval beech forest, while less thalli were mature, i.e., formed soredia or isidioid soredia (40.34\%; Fig. 6). This contrasts with studies, where the prevailing developmental stage of lichen was characterized as the reproduction by vegetative symbiotic propagules (Scheidegger 1995; Scheidegger et al. 2012). Sorediate individuals have been reported as dominated in populations (Mikryukov et al. 2010), while sterile thalli without vegetative propagules are of a comparatively short-living, transitional nature (Scheidegger et al. 1997; Scheidegger and Goward 2002).

Considerably higher levels of fertility are known from other regions, even not oldgrowth. That is, up to $25 \%$ of fertile thalli were indicated for the lichen population along the eastern cost of North America (Denison 2003), $30 \%$ for SW Finland (Carlsson and Nilsson 2009), $32 \%$ from the NE of the Altai Mountains (Mikryukov 2011), $36 \%$ for wooded meadows of Estonia (Jüriado et al. 2012). Following, we also expected higher presence of fertile thalli in the studied primeval forest. However, the only nearly $3 \%$ of total thalli harboured fruit bodies in Uholka-Shyrokyi Luh (Figs. 1b, 6).

Thus we interpret the high percentage of sterile thalli, a relatively small average size of individuals and the low frequency of fertile thalli as a signature of a growing population of 
L. pulmonaria within the primeval beech forest of Uholka-Shyrokyi Luh. We conclude that in this specific primeval beech forest under a continental, relatively dry climate harbours a very low density and abundance of L. pulmonaria. Increased population density of L. pulmonaria may occur next to a gap where light availability can support the growth during several decades until the next cohort of trees creates a light limited environment for the epiphytic lichen and bryophyte community at the trunks. Several cohorts of beech trees were however found to harbour L. pulmonaria within the same area (Fig. 7e), thus enabling a vast temporal connectivity at a small spatial scale. Additional evidence of spatio-temporal connectivity is the presence of the lichenicolous fungus Plectocarpon lichenum in several populations. Because this is a host-specific parasymbiont on L. pulmonaria its availability indicates the continuous presence of this lichen species (Ertz et al. 2005).

There is, however, an alternative hypothesis to explain the low frequency of reproducing individuals. Transboundary air pollution has possibly decreased the population frequency, abundance and portion of developmental stages during former decades. The decline in fertile specimens and total vitality has earlier been demonstrated for L. pulmonaria relating with acid rain (Öckinger et al. 2005) and ozone (Scheidegger and Schroeter 1995). Thus, the populations could also have suffered under elevated levels of air pollutants, including acid rain that was higher before 1990s (Oulehle et al. 2010; Šebesta et al. 2011; Vestreng et al. 2007). The pollution by acid rains and heavy metals are known from the surrounding regions of the Uholka-Shyrokyi Luh, as Ivano-Frankivsk and Chernivtsi regions in Ukrainian Carpathians (Shparyk and Parpan 2004), Romanian Transilvania (Lacatusu et al. 2001) and Romanian part of Eastern Carpathians (Donisa et al. 2000). The accumulation of heavy metals and radioactive elements were reported for lichens growing in Romanian Carpathians (Bartok 1988; Purvis et al. 1999). Accounting north-eastern crossroads for the air pollutant in upper troposphere (Lelieveld et al. 2002), it is likely that some environmental pollution also influenced our study area, especially because L. pulmonaria prefer eastern slopes (Fig. 7c). We showed that juvenile individuals tended to grow more densely at higher altitudes and at trees with small diameter (Fig. 7b, e). This may indicate substantial colonization of younger trees and spread to higher altitudes in the studied area. A possible explanation is that the highest elevations have been most affected by transboundary air pollution (Eilers et al. 1994). This could explain, why regeneration of L. pulmonaria is now more pronounced at high altitudes after a substantial decrease of transboundary air pollutants.

The decline of the lichens of Lobarion community was reported from the western part of Transcarpathians (Kondratyuk et al. 1998) and authors hypothesized possible relations with long-range atmospheric pollution during pre-1980s. Thus, transboundary air pollution may be suggested as a possible explanation for the untypical ratio of $L$. pulmonaria developmental stages observed in the study area. Recently this negative effect has decreased (Vestreng et al. 2007) and allows the lichen's regeneration either by vegetative dispersal or by regenerations of remnants of lobes. Therefore the low frequency and abundance of the lichen together with a low frequency of reproducing individuals is the consequence of elevated levels of air pollution during past decades. The high portion of trees that are colonized with juvenile thalli only can be considered an indication of a growing population since air quality has improved during the last 15 years or so. The high stand-structural diversity of the primeval forest landscape has obviously provided enough safe sites for the survival of $L$. pulmonaria over the entire area. This contrasts with other areas where the species went locally extinct because of air pollution (Wirth 1995). Because detailed data on air quality inside the primeval forest area are not available, we suggest that the 
environmental pollution hypothesis has to be tested in the framework of a long-term monitoring of the L. pulmonaria population and its developmental stages in the primeval beech forest of Uholka-Shyrokyi Luh.

\section{Conclusions}

This is the first analysis of the occupancy and density of Lobaria pulmonaria, including its developmental stages in the largest primeval beech forest in Europe using a non-stratified sampling design of over 10,000 ha. The total 483 trees harbouring L. pulmonaria were distributed very scattered within Uholka-Shyrokyi Luh, and occupied nearly $10 \%$ of studied perimeter. The GLMs showed that altitude and canopy cover influenced the presence of $L$. pulmonaria in the primeval beech forest, while the density of its populations was mostly affected by habitat type and slope aspect. We showed a bimodal distribution of L. pulmonaria which is frequent both below and above elevations of $900 \mathrm{~m}$, between beech forest stands with loose and scattered canopy in the generally dense canopy of the primeval beech forest of Uholka-Shyrokyi Luh. The habitat shift enables L. pulmonaria to survive also in dense forest canopy by climbing high up along a host tree trunk to get the necessary level of insolation. In general, L. pulmonaria occupied trees with various diameters, but juvenile individuals are more frequent on small trees, while mature individuals were found on trees of average or large sizes. Fertile individuals require specific environmental conditions such as intermediate altitudes, favorable light conditions, and flat terraces in eastern expositions of the slopes. Overall, the primeval beech forest of Uholka-Shyrokyi Luh harbours a high percentage of juvenile thalli of $L$. pulmonaria without any vegetative propagules and a low frequency of fruit bodies. We interpret this as an indication of a growing population of L. pulmonaria within the area. In earlier decades transboundary air pollution has likely decreased the lichens' population occupancy and density.

The pronounced distribution pattern of L. pulmonaria within the largest European primeval beech forest, described here, has consequences for the understanding of lichens as indicator species of woodland ecological continuity (Whittet and Ellis 2013). A significant association of a putative indicator species with old-growth forest patches can only be expected within a narrowly defined ecological niche of the indicator species. Given the relatively dry regional climatic conditions of Eastern Europe the niche of L. pulmonaria in the primeval forest is limited to the bottom of valleys with continuously high relative air humidity and zones at higher altitude. Furthermore, indicators of ecological continuity are often rare species even within their niche and they show a patchy distribution pattern. Interactions between climatic conditions, habitat preferences and occurrence of indicator species can only be well-understood in large primeval forest reserves. Reserves, like the Uholka-Shyrokyi Luh primeval forest, are thus unique reference ecosystems to study complex interactions between primeval forest lichens and their environment.

Acknowledgments We are very indebted to Brigitte Commarmot and Martina Hobi for the critical revision of this manuscript, and Silvia Dingwall (all Birmensdorf, Switzerland) for improving the English. We thank Brigitte Commarmot (Birmensdorf, Switzerland), Ruedi Iseli and Beate Hasspacher (Olten, Switzerland), as well as Mykola Korol (Lviv, Ukraine) for their support during exploration of this project. We also grateful to Vasyl Naumovich (Kherson, Ukraine), Olexander Ordynets (Kharkiv, Ukraine), Volodymyr Savchyn (Lviv, Ukraine) and colleagues from the Carpathian Biosphere Reserve and Ukrainian National Forestry University for assisting with the field work. This Project was funded by the Swiss State Secretariat for Education, Research and Innovation (SERI). 
Conflict of interest There is no conflict of interest declared.

\section{References}

Akaike H (1974) A new look at the statistical model identification. IEEE Trans Autom Control 19:716-723

Barry RG (1981) Mountain weather and climate. Elsevier B.V., University of Colorado, Boulder

Bartok K (1988) Heavy metal distribution in several lichen species in a polluted area. Rev Roum Biol Ser Biol Veg 33:127-134

Bengtsson J, Angelstam P, Elmqvist T et al (2003) Reserves, resilience and dynamic landscapes. Ambio 32:389-396

Bollmann K, Braunisch V (2013) To integrate or to segregate: balancing commodity production and biodiversity conservation in European forests. In: Kraus D, Krumm F (eds) Integrative approaches as an opportunity for the conservation of forest biodiversity. EFI, Joensuu, pp 18-31

Brändli U-B, Dowhanytsch J (2003) Urwälder im Zentrum Europas. Ein Naturführer durch das KarpatenBiosphärenreservat in der Ukraine. Hrsg. von der Eidgenössischen Forschungsanstalt WSL und Karpaten-Biosphärenreservat, Rachiw, Haupt Verlag, Bern, Stuttgart, Wien

Breckle SW (2002) Walter's vegetation of the earth: the ecological systems of the geo-biosphere. Springer, Heidelberg

Bruun HH, Moen J, Virtanen R et al (2006) Effects of altitude and topography on species richness of vascular plants, bryophytes and lichens in alpine communities. J Veg Sci 17:37-46

Büdel B, Scheidegger C (2008) Thallus morphology and anatomy. In: Nash TH III (ed) Lichen biology. Cambridge University Press, Cambridge, pp 40-68

Bursak VP (1997) The climate. In: Movchan Ya, Hamor F, Sheliag-Sosonko Yu, Dudka I, Zahorodniuk I (eds) Biodiversity of the Carpathian Biosphere Reserve. Interecocentr, Kiev, pp 69-80

Carlsson R, Nilsson K (2009) Status of the red-listed lichen Lobaria pulmonaria on the Aland Islands, SW Finland. Ann Bot Fenn 46:549-554

Commarmot B, Bachofen H, Bundziak Y et al (2005) Structures of virgin and managed beech forests in Uholka (Ukraine) and Sihlwald (Switzerland): a comparative study. For Snow Landsc Res 79:45-56

Commarmot B, Brändli U-B, Hamor F, Lavnyy V (2013) Inventory of the Largest Primeval Beech Forest in Europe-a Swiss-Ukrainian scientific adventure. Swiss Federal Research Institute WSL, Birmensdorf; Ukrainian National Forestry University, L'viv; Carpathian Biosphere Reserve, Rakhiv

Coxson D, Stevenson S, Campbell J (2003) Short-term impacts of partial cutting on lichen retention and canopy microclimate in an Engelmann spruce-subalpine fir forest in north-central British Columbia. Can J For Res 33:830-841

Dal Grande F, Widmer I, Wagner HH, Scheidegger C (2012) Vertical and horizontal photobiont transmission within populations of a lichen symbiosis. Mol Ecol 21:3159-3172

Denison WC (2003) Apothecia and ascospores of Lobaria oregana and Lobaria pulmonaria investigated. Mycologia 95:513-518

Donisa C, Mocanu R, Steinnes E, Vasu A (2000) Heavy metal pollution by atmospheric transport in natural soils from the northern part of eastern Carpathians. Water Air Soil Pollut 120:347-358

Dymytrova L, Nadyeina O, Hobi M, Scheidegger C (2014) Topographic and forest-stand variables determining epiphytic lichen diversity in the primeval beech forest in the Ukrainian Carpathians. Biodivers Conserv 23:1367-1394

Edman M, Eriksson AM, Villard MA (2008) Effects of selection cutting on the abundance and fertility of indicator lichens Lobaria pulmonaria and Lobaria quercizans. J Appl Ecol 45:26-33

Eilers JM, Rose CL, Sullivan TJ (1994) Status of air quality and effects of atmospheric pollutants on ecosystems in the Pacific Northwest Region of the National Park Service. US Department of the Interior, National Park Service

Ertz D, Christnach C, Wedin M, Diederich P (2005) A world monograph of the genus Plectocarpon (Roccellaceae, Arthoniales). Bibl Lichenol 91:1-155

Fritz Ö, Niklasson M, Churski M (2009) Tree age is a key factor for the conservation of epiphytic lichens and bryophytes in beech forests. Appl Veg Sci 12:93-106

Gauslaa Y (1994) Lobaria pulmonaria, an indicator of species-rich forests of long ecological continuity. Blyttia 52:119-128

Groom MJ, Meffe GK, Carroll CR (2006) Principles of conservation biology. Sinauer Associates, Sunderland

Gu WD, Kuusinen M, Konttinen T, Hanski I (2001) Spatial pattern in the occurrence of the lichen Lobaria pulmonaria in managed and virgin boreal forests. Ecography 24:139-150 
Gustafsson L, Fiskesjo A, Ingelog T et al (1992) Factors of importance to some lichen species of deciduous broad-leaved woods in southern Sweden. Lichenologist 24:255-266

Hakulinen R (1964) Die Flechtengattung Lobaria Schreb. in Ostfennoskandien. Ann Bot Fenn 1:202-213

Hansson L (1997) Boreal ecosystems and landscape structures, functions and conservation of biodiversity. Ecol Bull 46:140-170

Hilmo O, Rocha L, Holien H, Gauslaa Y (2011) Establishment success of lichen diaspores in young and old boreal rainforests: a comparison between Lobaria pulmonaria and L. scrobiculata. Lichenologist 43:241-255

Høistad F, Gjerde I (2011) Lobaria pulmonaria can produce mature ascospores at an age of less than 15 years. Lichenologist 43:495-497

Honegger R, Scherrer S (2008) Sexual reproduction in lichen-forming ascomycetes. In: Nash TH III (ed) Lichen biology. Cambridge University Press, Cambridge, pp 94-103

James PW, Hawksworth DL, Rose F (1977) Lichen communities in the British Isles: a preliminary conspectus. In: Seaward MRD (ed) Lichen ecology. Academic Press, London, pp 295-413

Jüriado I, Liira J, Csencsics D et al (2011) Dispersal ecology of the endangered woodland lichen Lobaria pulmonaria in managed hemiboreal forest landscape. Biodivers Conserv 20:1803-1819

Jüriado I, Karu L, Liira J (2012) Habitat conditions and host tree properties affect the occurrence, abundance and fertility of the endangered lichen Lobaria pulmonaria in wooded meadows of Estonia. Lichenologist 44:263-276

Kalwij JM, Wagner HH, Scheidegger C (2005) Effects of stand-level disturbances on the spatial distribution of a lichen indicator. Ecol Appl 15:2015-2024

Kondratyuk S, Coppins B, Zelenko S et al (1998) Lobarion lichens as indicators of primeval forests in the Ukrainian part of the proposed trilateral reserve "Eastern Carpathians". In: Kondratyuk SY, Coppins BJ (eds) Lobarion lichens as indicators of the primeval forests of the Eastern Carpathians. M.H. Kholodny Institute of Botany, Ukrainian Phytosociological Centre, Kiev, pp 64-79

Körner C (2007) The use of 'altitude' in ecological research. Trends Ecol Evol 22:569-574

Kuusinen M (1994) Epiphytic lichen diversity on Salix caprea in old-growth southern and middle boreal forests of Finland. Ann Bot Fenn 31:77-92

Kuusinen M (1996) Cyanobacterial macrolichens on Populus tremula as indicators of forest continuity in Finland. Biol Conserv 75:43-49

Lacatusu R et al (2001) Soil pollution by acid rains and heavy metals in Zlatna region, Romania. In: Stott DE, Mohtar RH, Steinhardt GC (eds) Sustaining the global farm. Purdue University, West Lafayette, pp 817-820

Lanz A (2011) Auswertung von Waldinventuren-Formeln mit Zahlenbeispielen. Arbeitspapier. Eidg. Forschungsanstalt für Wald, Dietikon

Lelieveld J, Berresheim H, Borrmann S et al (2002) Global air pollution crossroads over the Mediterranean. Science 298:794-799

Mikhailova I, Trubina M, Vorobeichik E, Scheidegger C (2005) Influence of environmental factors on the local-scale distribution of cyanobacterial lichens: case study in the North Urals, Russia. Folia Cryptogam Est 41:45-54

Mikryukov VS (2011) Population ecology of the epiphytic lichen Lobaria pulmonaria (L.) Hoffm. in Ural and Siberia. PhD Thesis, Yekatirinburg University of Plant and Animal Ecology

Mikryukov VS, Mikhailova IN, Scheidegger C (2010) Reproductive parameters of Lobaria pulmonaria (L.) Hoffm. in the Urals. Russ J Ecol 41:475-479. doi:10.1134/s1067413610060032

Nascimbene J, Benesperi R, Brunialti G et al (2013) Patterns and drivers of $\beta$-diversity and similarity of Lobaria pulmonaria communities in Italian forests. J Ecol 101:493-505

Nilsson S, Arup U, Baranowski R, Ekman S (1995) Tree-dependent lichens and beetles as indicators in conservation forests. Conserv Biol 9:1208-1215

Öckinger E, Nilsson SG (2010) Local population extinction and vitality of an epiphytic lichen in fragmented old-growth forest. Ecology 91:2100-2109

Öckinger E, Niklasson M, Nilsson SG (2005) Is local distribution of the epiphytic lichen Lobaria pulmonaria limited by dispersal capacity or habitat quality? Biodivers Conserv 14:759-773

Otalora MG, Martinez I, Belinchon R et al (2011) Remnants fragments preserve genetic diversity of the old forest lichen Lobaria pulmonaria in a fragmented Mediterranean mountain forest. Biodivers Conserv 20:1239-1254

Oulehle F, Hleb R, Houška J, Šamonil P, Hofmeister J, Hruška J (2010) Anthropogenic acidification effects in primeval forests in the Transcarpathian Mts., western Ukraine. Sci Total Environ 408:856-864

Pannewitz S, Schroeter B, Scheidegger C, Kappen L (2003) Habitat selection and light conditions: a field study with Lobaria pulmonaria. Bibl Lichenol 86:281-297 
Pickett STA, Thompson JN (1978) Patch dynamics and the design of nature reserves. Biol Conserv $13: 27-37$

Poelt J (1987) Das Gesetz der relativen Standortskonstanz bei den Flechten Botanische Jahrbücher. Systematik 108:363-371

Purvis W, Williamson B, Bartók K, Rusu A-M, Dubbin B (1999) Accumulation of particulates (PM10's) by lichens in the vicinity of an ore processing plant, Zlatna, Romania. In: Anonymous (ed) International conference on lichen conservation biology, Licons. Swiss Federal Institute for Forest, Snow and Landscape Research, Birmensdorf

Pykälä J (2004) Effects of new forestry practices on rare epiphytic macrolichens. Conserv Biol 18:831-838

R Development Core Team (2011) R: a language and environment for statistical computing. R Foundation for Statistical Computing, Vienna. http://www.R-project.org/. Accessed 1 Sept 2013

Roberts DW (1986) Ordination on the basis of fuzzy set theory. Vegetatio 66:123-131

Rose F (1976) Lichenological indicators of age and environmental continuity in woodlands. In: Brown DH, Hawksworth DL, Bailey RH (eds) Lichenology: progress and problems. Academic Press, London, pp 279-307

Rose F (1988) Phytogeographical and ecological aspects of Lobarion communities in Europe. Bot J Linn Soc 96:69-79

Rose F (1992) Temperate forest management: its effects on bryophyte and lichen floras and habitats. In: Bates JW, Farmer A (eds) Bryophytes and lichens in a changing environment. Clarendon Press, Oxford, pp 211-233

Scheidegger C (1991) Phytogeography of the lichen genus Buellia (Physciaceae, Lecanorales) in Mediterranean Europe. Bot Chron 10:211-220

Scheidegger C (1995) Early development of transplanted isidioid soredia of Lobaria pulmonaria in an endangered population. Lichenologist 27:361-374

Scheidegger, Goward T (2002) Monitoring lichens for conservation: Red Lists and conservation action plans. In: Nimis PL, Scheidegger C, Wolseley P (eds) Lichen monitoring-monitoring lichens. Kluwer, Dordrecht, pp 163-181

Scheidegger C, Schroeter B (1995) Effects of ozone fumigation on epiphytic macrolichens-ultrastructure, $\mathrm{CO}_{2}$ gas-exchange and chlorophyll fluorescence. Environ Pollut 88:345-354

Scheidegger C, Werth S (2009) Conservation strategies for lichens: insights from population biology. Fungal Biol Rev 23:55-66

Scheidegger C, Flachsmann S, Zoller S, Frey B (1997) Naturschutzbiologie bei Flechten: Konzepte und Projekte. In: Schöller H (ed) Flechten: Geschichte, Biologie, Systematik, Ökologie, Naturschutz und kulturelle Bedeutung; Begleitheft zur Ausstellung "Flechten - Kunstwerke der Natur". Kleine Senckenbergische Reihe Nr. 27. Kramer, Frankfurt am Main, pp 167-175

Scheidegger C, Bergamini A, Bürgi M et al (2010) Waldwirtschaft. In: Lachat T, Pauli D, Gonseth Y, Klaus G, Scheidegger C, Vittoz P, Walter T (eds) Wandel der Biodiversität in der Schweiz seit 1900 - ist die Talsohle erreicht?. Haupt, Bern, pp 124-160

Scheidegger C, Bilovitz PO, Werth S, Widmer I, Mayrhofer H (2012) Hitchhiking with forests: population genetics of the epiphytic lichen Lobaria pulmonaria in primeval and managed forests in southeastern Europe. Ecol Evol 2:2223-2240. doi:10.1002/ece3.341

Schoener TW (1975) Presence and absence of habitat shift in some widespread lizard species. Ecol Monogr 45:233-258. doi:10.2307/1942423

Šebesta J, Šamonil P, Lacina J, Oulehle F, Houška J, Buček A (2011) Acidification of primeval forests in the Ukraine Carpathians: vegetation and soil changes over six decades. For Ecol Manag 262:1265-1279

Shparyk YS, Parpan VI (2004) Heavy metal pollution and forest health in the Ukrainian Carpathians. Environ Pollut 130:55-63. doi:10.1016/j.envpol.2003.10.030

Singh G, Dal Grande F, Cornejo C, Schmitt I, Scheidegger C (2012) Genetic basis of self-incompatibility in the lichen-forming fungus Lobaria pulmonaria and skewed frequency distribution of mating-type idiomorphs: implications for conservation. PLoS ONE 7:e51402. doi:10.1371/journal.pone.0051402

Stofer S, Scheidegger C, Clerc P et al (2008) SwissLichens - Webatlas der Flechten der Schweiz/Modul Verbreitung (Version 2 vom 3. 07. 2009). http://www.swisslichens.ch. Accessed 27 Nov 2012

Tibell L (1992) Crustose lichens as indicators of forest continuity in boreal coniferous forests. Nord J Bot 12:427-450

Trotsiuk V, Hobi ML, Commarmot B (2012) Age structure and disturbance dynamics of the relic virgin beech forest Uholka (Ukrainian Carpathians). For Ecol Manag 265:181-190. doi:10.1016/j.foreco. 2011.10.042

Van Teeffelen AJA, Vos CC, Opdam P (2012) Species in a dynamic world: consequences of habitat network dynamics on conservation planning. Biol Conserv 153:239-253. doi:10.1016/j.biocon.2012.05.001 
Vestreng V, Myhre G, Fagerli H, Reis S, Tarrason L (2007) Twenty-five years of continuous sulphur dioxide emission reduction in Europe. Atmos Chem Phys 7:3663-3681

Walser JC (2004) Molecular evidence for limited dispersal of vegetative propagules in the epiphytic lichen Lobaria pulmonaria. Am J Bot 91:1273-1276

Werth S, Wagner HH, Gugerli F, Holderegger R, Csencsics D, Kalwij JM, Scheidegger C (2006) Quantifying dispersal and establishment limitation in a population of an epiphytic lichen. Ecology 87:2037-2046

Werth S, Gugerli F, Holderegger R, Wagner HH, Csencsics D, Scheidegger C (2007) Landscape-level gene flow in Lobaria pulmonaria, an epiphytic lichen. Mol Ecol 16:2807-2815

Whittet R, Ellis CJ (2013) Critical tests for lichen indicators of woodland ecological continuity. Biol Conserv 168:19-23. doi:10.1016/j.biocon.2013.09.011

Widmer I, Dal Grande F, Excoffier L, Holderegger R, Keller C, Mikryukov VS, Scheidegger C (2012) European phylogeography of the epiphytic lichen fungus Lobaria pulmonaria and its green algal symbiont. Mol Ecol 21:5827-5844. doi:10.1111/mec.12051

Wirth V (1995) Die Flechten Baden-Württembergs. Eugen Ulmer, Stuttgart

Wolseley PA (1991) Observations on the composition and distribution of the Lobarion in forests of South East Asia. In: Galloway DJ (ed) Tropical lichens: their systematics, conservation and ecology, vol 43, Systematics Association special volumes. Clarendon Press, Oxford, pp 217-243

Yoshimura I (1971) The genus Lobaria of Eastern Asia. J Hattori Bot Lab 34:231-364

Zoller S, Lutzoni F, Scheidegger C (1999) Genetic variation within and among populations of the threatened lichen Lobaria pulmonaria in Switzerland and implications for its conservation. Mol Ecol 8:2049-2059 